\title{
TRANSFORMATION OF THE MIGRATION POLICY OF STATES DURING THE PANDEMIC PERIOD
}

\author{
Vladimir J. Zorin \\ Institute of Ethnology and Anthropology named after N.I. Miklouho-Maclay \\ of the Russian Academy of Sciences, Moscow, Russian Federation; \\ Financial University under the Government of the Russian Federation, Moscow, Russian Federation
}

\section{Vladimir A. Voloh}

State University of Management, Moscow, Russian Federation

\section{Vera A. Suvorova}

State University of Management, Moscow, Russian Federation

\begin{abstract}
Introduction. The article is devoted to the transformation of migration policies during the COVID-19 coronavirus pandemic. The article discusses changes in migration processes in connection with the COVID-19. The aim of the article is to illustrate how the countries' migration policy has changed due to the pandemic and what measures have been developed to support migrants. Methods and materials. The research methodology includes general scientific research methods, such as analysis, synthesis, content analysis and the aristotelian method. As well as specific scientific methods, such as comparative legal and system analysis. The empirical basis of the study is the data of the General Administration for Migration Issues of the Ministry of Internal Affairs of Russian Federation, the International Organization for Migration (IOM), and the United Nations (UN). Analysis. The authors conducted a comparative analysis of migration policies of various countries during the COVID-19 coronavirus pandemic. Considerable attention is paid to the measures taken by countries to provide various types of support to migrants. The authors also analyzed the activities of international organizations and the civil society. The authors concluded that measures to restrain the pandemic affected the implementation of funded integration projects in the European countries, some activities were postponed, however, the European countries made certain efforts to adopt new integration practices to support migrants during the COVID-19 pandemic. Discussion. The authors assessed the further development of migration processes and countries migration policies. Results. The authors effectuated a conclusion that the COVID-19 pandemic has had a significant impact on the transformation of migration processes and migration policies. The authors focused on how events in the migration sphere would develop, and what changes would take place in the migration policy of the Russian Federation. The research results $\vec{\widetilde{ }}$ presented in the article can be used to improve the migration policy of the Russian Federation in relation to labour iे migrants and to develop regulatory migration measures.

Key words: migration processes, transformation, migration policy of the Russian Federation, migration policy of foreign countries, pandemic of coronavirus infection COVID-19.

Citation. Zorin V.J., Voloh V.A., Suvorova V.A. Transformation of the Migration Policy of States During the Pandemic Period. Vestnik Volgogradskogo gosudarstvennogo universiteta. Seriya 4. Istoriya. Regionovedenie. Mezhdunarodnye otnosheniya [Science Journal of Volgograd State University. History. Area Studies. International Relations], 2021, vol. 26, no. 3, pp. 34-44. (in Russian). DOI: https://doi.org/10.15688/jvolsu4.2021.3.4
\end{abstract}




\title{
ТРАНСФОРМАЦИЯ МИГРАЦИОННОЙ ПОЛИТИКИ ГОСУДАРСТВ В ПЕРИОД ПАНДЕМИИ
}

\author{
Владимир Юрьевич Зорин \\ Институт этнологии и антропологии им. Н.И. Миклухо-Маклая РАН, \\ г. Москва, Российская Федерация; \\ Финансовый университет при Правительстве РФ, г. Москва, Российская Федерация
}

\section{Владимир Александрович Волох}

Государственный университет управления, г. Москва, Российская Федерация

\section{Вера Александровна Суворова}

Государственный университет управления, г. Москва, Российская Федерация

Аннотация. Введение. Статья посвящена вопросам трансформации миграционной политики стран в период пандемии коронавирусной инфекции COVID-19. Рассмотрены изменения миграционных процессов в связи с пандемией. Ставится цель показать, как изменилась миграционная политика государств из-за пандемии и какие меры разработали государства для оказания помощи мигрантам. Методы и материальы. При подготовке статьи авторами использовались как общенаучные методы исследования, такие как анализ, синтез, контент-анализ, формально-логический, так и частно-научные методы, такие как сравнительно-правовой и системный анализ. Эмпирической основой исследования выступают данные Главного управления по вопросам миграции МВД России, Международной организации по миграции (МОМ), Организации объединенных наций $(\mathrm{OOH})$. Анализ. Авторами проведен сравнительный анализ миграционной политики различных государств в период пандемии коронавирусной инфекции COVID-19. Значительное внимание уделяется мерам, предпринятым государствами для оказания различного рода помощи мигрантам. Авторами также проведен анализ деятельности международных организаций и гражданского общества. Делается вывод, что меры по сдерживанию пандемии повлияли на реализацию финансируемых интеграционных проектов в европейских странах, некоторые мероприятия были отложены, но несмотря на это европейские страны постарались внедрить новые практики интеграции для оказания помощи мигрантам в период пандемии COVID-19. Дискуссия. Авторами приводится оценка дальнейшего развития событий, связанных с миграционными процессами и миграционной политикой государств. Peзультатьl. Авторами делается вывод, что пандемия COVID-19 оказала значительное влияние на трансформацию миграционных процессов и миграционной политики государств. Авторы акцентируют внимание на том, как дальше будут развиваться события в миграционной сфере, какие изменения будут происходить в миграционной политике Российской Федерации. Изложенные в статье результаты исследования могут быть востребованы для совершенствования государственной миграционной политики Российской Федерации в отношении трудовых мигрантов и разработки регулирующих миграционных мероприятий. Вклад авторов. В.Ю. Зорин разработал контент статьи и осуществил ее общую научную редакцию. В.А. Волох проанализировал миграционную политику Российской Федерации и концепцию нового миграционного закона. В.А. Суворова проанализировала миграционную политику зарубежных государств и предложила схему исследовательского анализа.

Ключевые слова: миграционные процессы, трансформация, миграционная политика Российской Федерации, миграционная политика зарубежных стран, пандемия коронавирусной инфекции COVID-19.

Цитирование. Зорин В. Ю., Волох В. А., Суворова В. А. Трансформация миграционной политики государств в период пандемии // Вестник Волгоградского государственного университета. Серия 4, История. Регионоведение. Международные отношения. - 2021. - Т. 26, № 3. - C. 34-44. - DOI: https://doi.org/10.15688/ jvolsu4.2021.3.4 


\section{ПРОГНОЗНЫЕ СЦЕНАРИИ ПОЛИТИЧЕСКИХ ТРАНСФОРМАЦИЙ}

Введение. С момента первоначального сообщения от 31 декабря 2019 г. болезнь, известная как коронавирусная инфекция COVID-19, быстро распространилась по всему миру, что побудило Всемирную организацию здравоохранения (ВО3) объявить ее пандемией 11 марта 2020 года.

Вспышка COVID-19 нанесла серьезный ущерб социально-экономической деятельности, что привело к серьезной рецессии мировой экономики. Большинство стран отреагировали быстро и с самого начала кризиса попытались создать беспрецедентный пакет мер для рынка труда и социальной политики, направленный на снижение экономического шока и поддержку работников.

Согласно прогнозу занятости ОЭСР-2020, даже в более оптимистичном сценарии развития пандемии уровень безработицы в государствах-членах ОЭСР может достичь 9,4 \% в IV квартале 2020 г., превысив все пики со времен Великой депрессии. Средняя занятость в 2020 г. прогнозируется на уровне между 4,1 и $5 \%$ [1].

Пандемия COVID-19 повлияла на миграционные процессы в различных регионах, поскольку страны ограничили международные, трансграничные и внутренние перемещения, чтобы свести к минимуму распространение и воздействие пандемии. По состоянию на июнь 2020 г. $6 \%$ аэропортов, $25 \%$ пунктов пересечения сухопутной границы и 9 \% пунктов пересечения морской границы были закрыты для въезда и выезда в Европейской экономической зоне [9]. По данным Frontex, количество нелегальных пересечений границ сократилось на 85 \% по сравнению с предыдущим месяцем и составило около 900 [14].

Количество ходатайств о предоставлении убежища в I квартале 2020 г. оставалось на уровне того же периода в 2019 г., а затем значительно сократилось в связи с продолжающейся пандемией COVID-19 и соответствующими чрезвычайными мерами, введенными государствами-членами ЕС, включая приостановку регистрации заявок.

Пандемия также повлияла на занятость и интеграцию мигрантов, поскольку меры по закрытию и социальному дистанцированию оказали влияние на административные процедуры получения разрешений на проживание и работу, а также на программы интеграции мигрантов [8].

В Российской Федерации, по данным Главного управления по вопросам миграции МВД России, с учетом приостановления на период с 15 марта по 15 июня 2020 г. отмечается уменьшение численности оформленных разрешений на работу на 56,3 \% (с 48,7 тыс. до 21,3 тыс.) и на $30,5 \%$ патентов (с 841,9 тыс. до 585 тыс.). В январе - апреле 2020 г. зафиксировано 4,1 млн фактов постановки иностранных граждан на миграционный учет (-20,3 \%), в том числе по месту жительства - 145,3 тыс. $(-22,6 \%)$, по месту пребывания - 3,9 млн $(-20,2 \%)$, количество фактов снятия с миграционного учета $-3,4$ млн $(-7,1 \%)$. В первые три месяца 2020 г. количество оформленных (переоформленных) патентов ежемесячно увеличивалось, а в апреле в сравнении с мартом текущего года отмечено их снижение на 39,6 \%. При этом наибольший темп снижения наблюдается по оформлению патентов $-40,7 \%$, по переоформленным документам снижение составило $24 \%$. Снижение показателей связано с ситуацией в мире и мерами, принимаемыми Российской Федерацией по нераспространению коронавирусной инфекции.

По данным МВД России в период действия в стране ограничительных мер, связанных с распространением коронавирусной инфекции COVID-19, количество совершенных иностранцами преступлений в сравнении с аналогичным периодом предыдущего года снизилось на 11,4 \% (2,8 тыс.).

Методы и материалы. При подготовке статьи авторами были использованы: общенаучные методы исследования, такие как анализ, синтез, контент-анализ, формальнологический. В качестве частно-научных методов использованы сравнительно-правовой и системный анализ для раскрытия процессов трансформации миграционной политики в период пандемии коронавирусной инфекции COVID-19.

В качестве эмпирической базы исследования были использованы официальные материалы Главного управления по вопросам миграции МВД России, Международной организации по миграции (МОМ), Организации объединенных наций $(\mathrm{OOH})$, официальные выступ- 
ления и заявление руководителей государств по обозначенной в работе тематике.

Анализ. Возникновение нового вируса COVID-19 нанесло серьезный удар по экономике государств. На фоне пандемии на рынке труда стран произошло резкое сокращение рабочих мест, особенно в тех отраслях, где были заняты мигранты. В результате многие трудовые мигранты вернулись в свои страны с помощью двусторонних переговоров, которые позволили временно открыть границы для их возвращения. Так, по данным МОМ, более 230000 афганцев без документов вернулись из Ирана и Пакистана в период с 1 марта 2020 г. по 30 мая 2020 г. [12].

Меры, направленные на сдерживание последствий пандемии, оказали непосредственное влияние на миграционную политику государств. Миграционная политика стран сильно различалась между собой, от полного закрытия границ для международных мигрантов до частичного. Кроме того, анализ оценок показателей управления миграцией (MGI), проведенный в период между 2018 и 2020 гг. до пандемии COVID-19, показал, что страны предоставляли мигрантам различную степень доступа к финансируемым государством медицинским услугам в зависимости от их миграционного статуса. Анализ, который охватил 51 страну, показал, что треть этих стран предоставляли одинаковый доступ к медицинской помощи как гражданам, так и мигрантам, независимо от их миграционного статуса. В половине опрошенных стран равный доступ к медицинской помощи зависел от миграционного статуса. Кроме того, 12 \% стран предоставляли мигрантам доступ только к некоторым медицинским услугам, включая неотложную медицинскую помощь [10].

Например, США стали первой страной, обосновавшей ограничения иммиграции для защиты рынка труда. Президент США Д. Трамп 22 апреля 2020 г. издал Указ о приостановлении выдачи виз определенным категориям постоянных иммигрантов, которые «представляют риск для рынка труда США во время восстановления экономики после вспышки COVID-19». Согласно Указу в течение 60 дней иммиграция из-за рубежа была ограничена супругами и несовершеннолетними детьми граждан США и инвесторами-им- мигрантами, которые инвестируют не менее 900000 долларов в бизнес США. Такие страны, как Перу, Эквадор, Намибия полностью закрыли свои границы для мигрантов. Другие страны из-за нехватки трудовых ресурсов в различных отраслях экономики сделали определенные исключения. Так, Италия приняла предложение Кубы направить медицинский персонал в страну для оказания помощи больным коронавирусом. Германия и Соединенное Королевство организовали специальные чартерные рейсы для прилета сельскохозяйственных рабочих из Румынии, чтобы они оказали помощь в снятии урожая [15].

Некоторые страны предоставили мигрантам льготы или помощь. Например, в Португалии все иностранные граждане, ожидающие рассмотрения заявлений на иммиграцию, в том числе лица, ищущие убежища, были временно рассмотрены как постоянные жители, что позволило им получить доступ к медицинской помощи и другим льготам. Великобритания предоставила автоматическое продление статуса для многих временных работников, включая врачей, медсестер и медработников на один год. Китай автоматически продлевал разрешения на работу и проживание и оказывал социальную поддержку трудовым мигрантам, пострадавшим от коронавируса. Италия, нуждающаяся в трудовых мигрантах в отрасли сельского хозяйства, утвердила пути упорядочения статуса сельскохозяйственных работников и работников по уходу за домом [8].

В Польше 21 июня 2020 г. вступил в силу закон о введении пособия для людей, потерявших работу из-за пандемии COVID-19. Данное пособие распространяется в том числе на 3 категории иностранцев. Первая категория иностранцы, имеющие временный вид на жительство или рабочую визы. Вторая категория - иностранцы, имеющие вид на жительство в Польше, и третья категория - иностранцы, имеющие статус беженца, лица, пользующиеся дополнительной защитой [11].

Правительство Испании ввело дополнительные меры для безопасного выполнения процедур интеграции мигрантов и лиц, ищущих убежище. Интервью с беженцами и лицами, ищущими убежища, которые обратились за такой помощью, проводились по телефону 


\section{ПРОГНОЗНЫЕ СЦЕНАРИИ ПОЛИТИЧЕСКИХ ТРАНСФОРМАЦИЙ}

с синхронным переводом. В Дании для оказания помощи беженцам во время пандемии была создана специальная горячая линия и организована он-лайн помощь с учебой для детей-беженцев при поддержке НПО Датский совет по делам беженцев [13].

В Австрии кампания ÖIF использовала SMS для информирования 70000 беженцев и мигрантов о том, как найти информацию, связанную с коронавирусом. ÖIF также создала горячую линию для вопросов о коронавирусе, которая поддерживается на 9 языках. Сотрудники кампании оказывают информационную помощь по телефону и электронной почте лицам, имеющим право на убежище и дополнительную защиту, по телефону и электронной почте для получения информации и консультаций.

В Чешской Республике группа матерей из вьетнамской общины организовала пошив масок и другие формы поддержки беженцам. Они сшили и пожертвовали более 13000 масок для лица, а также собрали средства, чтобы помочь больницам приобрести вентиляторы. В Португалии один муниципалитет подготовил 500 мест для карантина на случай необходимости изоляции иностранных работников сельского хозяйства. Правительство Португалии также опубликовало технический документ о получении медицинской помощи, предназначенный для медицинских работников, а также мигрантов и беженцев [8].

Одной из трудностей этой пандемии стало поддержание социальных контактов, когда встречи и мероприятия отменялись и действовали правила физического дистанцирования, что оказалось особенно трудным для мигрантов, которые не успели адаптироваться в принимающем государстве. Так, например, в Швеции была запущена онлайн-инициатива по изучению шведского языка, которая устанавливает виртуальные встречи между мигрантом и шведом, помогая решить проблемы языкового обучения. Во Франции были организованы языковые курсы для иммигрантов посредством дистанционного обучения.

Кроме того, следует отметить деятельность международных организаций и гражданского общества в период пандемии. Международная организация по миграции оказала помощь более 15300 мигрантам, которые вер- нулись в Эфиопию из Саудовской Аравии и других африканских стран и были помещены на карантин. Международная организация труда (МОТ) разработала рекомендации, которые помогут в разработке мер, обеспечивающих защиту трудовых мигрантов. МОТ предложило государствам расширить доступ к медицинским услугам и социальной защите трудовых мигрантов, предоставить всем трудовым мигрантам доступ к средствам правовой защиты, создать благоприятные условия для диалога между работодателями и мигрантами [3].

В связи с ростом дискриминационных настроений и насильственных действий в Европе по отношению к мигрантам, акторы гражданского общества предприняли ряд мер, например, голландская антидискриминационная организация запустила онлайн-кампанию, чтобы побудить людей высказаться против предрассудков и дискриминации в результате пандемии. Европейская сеть против расизма (ENAR) опубликовала документ, освещающий влияние COVID-19 на расовые общины.

Что касается миграционной политики Российской Федерации, то следует отметить, что МВД России последовательно принимались все необходимые меры для урегулирования правового положения иностранных граждан, находящихся на территории России и не имеющих возможности выехать на родину. Так, с 19 марта 2020 г. независимо от цели въезда всем иностранным гражданам была предоставлена возможность обратиться с заявлением о продлении срока действия разрешительных документов.

В соответствии с Указом Президента Российской Федерации от 18 апреля 2020 г. № 274 для всех иностранных граждан, прибывших в Россию как в визовом, так и безвизовом порядке, на период с 15 марта по 15 июня 2020 г. приостановилось течение сроков временного пребывания, временного или постоянного проживания, а также сроков, на которые иностранные граждане поставлены на учет по месту пребывания или зарегистрированы по месту жительства (в случае, если такие сроки истекают в указанный период) [5].

Таким образом, всем иностранным гражданам, находящимся на территории Российс- 
кой Федерации, срок действия документов, который истек в указанный период, продлевался автоматически.

К разрешительным документам относятся: виза, разрешение на временное проживание, вид на жительство, миграционная карта, а также проставленные в ней отметки с истекающими сроками действия, удостоверение беженца, свидетельство о рассмотрении ходатайства о признании беженцем на территории Российской Федерации по существу, свидетельство о предоставлении временного убежища на территории Российской Федерации, свидетельство участника Государственной программы, разрешение на работу, патент, разрешение на привлечение и использование иностранных работников.

В соответствии с Указом в период с 15 марта по 15 июня 2020 г. в отношении иностранных граждан не принимались решения о нежелательности пребывания, об административном выдворении, депортации, реадмиссии, лишении статуса беженца или временного убежища, об аннулировании ранее выданных виз, разрешений на временное проживание, видов на жительство, разрешений на работу, патентов и свидетельств участника Госпрограммы переселения соотечественников.

Таким образом, можно сделать вывод о том, что меры по сдерживанию пандемии повлияли на реализацию финансируемых интеграционных проектов в европейских странах, некоторые мероприятия были отложены, но несмотря на это европейские страны постарались внедрить новые практики интеграции для оказания помощи мигрантам в период пандемии COVID-19. В Российской Федерации основной акцент сделан на урегулировании правового положения мигрантов.

Дискуссия. Аналитики рейтингового агентства Moody's Investors Service прогнозируют ухудшение ситуации в российской экономике из-за пандемии коронавируса и обвала цен на нефть. По мнению аналитиков, сложившаяся ситуация приведет к ускорению внутрироссийской миграции в ближайшие два года. Согласно прогнозу, россияне будут стремиться в крупные экономические центры, изза чего менее развитые регионы столкнутся с долгосрочным падением доходов и замедлением экономического роста. Миграционный отток коснется прежде всего регионов с низкими доходами населения и слабой системой социальной поддержки населения, с высокой занятостью в секторе услуг, близких к более развитым регионам [7].

Институт исследований и экспертизы Внешэкономбанка (ВЭБ РФ) спрогнозировал рост безработицы в России до 7 \% в 2020 г., пик безработицы, по мнению экспертов, ожидался во II квартале, когда число безработных увеличится до $10 \%$ от экономически активного населения [6].

По мнению Директора центра миграционных исследований Д. Полетаева: «Стоит ожидать роста теневой составляющей рынка труда, где иностранные работники будут конкурировать с россиянами и в этом случае их конкурентными преимуществами будет более низкая почасовая ставка оплаты труда, на которую они будут согласны, и готовность работать в тяжелых условиях, в том числе с опасностью для здоровья. События 2020 г. увеличат количество иностранцев, желающих приобрести ВНЖ (вид на жительство) или гражданство РФ, особенно среди трудовых мигрантов, имеющих длительный опыт работы и пребывания в РФ» [2]. Также эксперт отмечает, что после окончания ограничительных мер, связанных с эпидемией коронавиру$\mathrm{ca}$, с одной стороны, возможно усиление эмиграции россиян из России, в том числе квалифицированных специалистов, на фоне экономического кризиса, с другой стороны, будет нарастать учебная миграция в Российскую Федерацию.

Президент Российской Федерации В.В. Путин в своем выступлении заявил, что Россия в связи с развитием экономики скоро столкнется с нехваткой рабочих рук, поэтому страна заинтересована в притоке трудовых мигрантов. Президент подчеркнул, что речь идет о «молодых, здоровых, образованных людях, которые либо готовы получить образование и влиться в рынок труда, либо прямо приступить к работе, имея нужный уровень квалификации». При этом Президент призвал учитывать состояние рынка труда в разных регионах, а также развитие социальной инфраструктуры, чтобы «приток мигрантов не нарушал права граждан России, чтобы не было проблем с получением образовательных ус- 


\section{ПРОГНОЗНЫЕ СЦЕНАРИИ ПОЛИТИЧЕСКИХ ТРАНСФОРМАЦИЙ}

луг, с переполненностью учреждений здравоохранения [4].

ОЭСР рассматривались два эпидемиологических сценария на ближайшие 18 месяцев: один, где вирус продолжает отступать и остается под контролем, и второй, когда вторая волна быстрого заражения вспыхивает позднее в 2020 году. Согласно прогнозам ОЭСР, безработица увеличится до 9,4\% в среднем по ОЭСР к концу 2020 г. (по сравнению с 5,3 \% в конце 2019 г.). В случае второй волны пандемии в конце 2020 г. уровень безработицы увеличится еще больше, до 12,6 \%. Более того, прогнозы указывают только на постепенное восстановление: уровень безработицы останется на уровне или выше пикового уровня, наблюдаемого во время мирового финансового кризиса, достигнув 7,7 \% к концу 2021 г. без второй волны (и 8,9 \% в случае второй волны), с существенными различиями между странами. Уровень безработицы в марте 2021 г. снизился до 6,5\%.

Изменения экономической ситуации в странах окажут влияние на миграционные процессы. В 2019 г. число международных мигрантов достигло отметки в 272 млн, что на 14 млн превышает данные за 2017 год. Женщины составляют 48 \% от общего числа мигрантов, около 38 млн - дети, 4,4 млн - международные студенты и 164 млн - трудовые мигранты. 75 \% мигрантов - люди трудоспособного возраста (20-64 лет). Почти 31 \% всех мигрантов проживают в Азии, 30 \% - в Европе, $26 \%$ - в Северной и Южной Америке, $10 \%$ - в Африке и $3 \%$ - в Океании [10].

По мнению ученых, миграционная политика государств может измениться в сторону ужесточения, поскольку многие государства увидели в закрытии границ во время пандемии определенные преимущества. С другой стороны, в результате нынешней пандемии спрос на квалифицированный медицинский персонал, вероятно, усугубится, а имеющиеся международные данные показывают, что как минимум 10 стран США, Испания, Италия, Германия, Франция, Великобритания, Бельгия, Нидерланды Канада и Швейцария зависят от иностранных работников в медицинской сфере. Кроме того, ужесточение миграционной политики может привести к росту нелегальной миг- рации, когда экономика стран будет восстанавливаться.

Результаты. Как показал проведенный анализ, пандемия COVID-19 оказала значительное влияние на трансформацию миграционных процессов и миграционной политики государств. Как будут дальше развиваться события, сложно прогнозировать, поскольку все зависит от того, как долго будут ощущаться последствия пандемии. Но вполне вероятно, что в условиях экономического спада и происходящих изменений на рынке труда некоторые явления будут продолжать влиять на форму и интенсивность миграции рабочей силы как внутри государств, так и на внешнюю трудовую миграцию.

По мнению авторов, некоторые категории иностранных работников, вероятно, будут менее востребованы для экономики принимающих стран в краткосрочной перспективе, например, те, которые работают в секторах, сильно пострадавших от пандемии, такие как производство, туризм и т. п. Другие могут оказаться еще более востребованными, например, медицинские работники.

Анализ миграционных политик стран показал, что страны предоставляют мигрантам различную степень доступа к финансируемым государством медицинским услугам в зависимости от их миграционного статуса, а также социальную защиту. Однако существует и ряд проблем, например, защита прав мигрантов. Поэтому авторы полагают, что Глобальный договор о безопасной, упорядоченной и легальной миграции становится очень важен. Один из принципов Глобального договора - обеспечение должного уважения, защиты и осуществление прав человека всех мигрантов, независимо от их миграционного статуса, на всех этапах миграционного цикла. Кроме того, складывающаяся на сегодняшний день ситуация с миграцией в Европе показывает, что руководящий принцип, который в первую очередь приводит в действие Глобальный договор о безопасной, упорядоченной и легальной миграции, остается в силе: государствам необходимо работать вместе, помимо двустороннего и регионального сотрудничества, чтобы найти более эффективные способы решения проблемы миграции. 
Анализ миграционной политики Российской Федерации показал, что государство в лице МВД России уже немало сделало, приняв оперативно ряд мер по продлению пребывания иностранных граждан на период кризиса в целях недопущения роста неурегулированных мигрантов. Такую работу, по мнению авторов, важно продолжить, распространив процесс на все категории мигрантов, которые вследствие кризиса могут оказаться в проблемной ситуации, в частности, на высококвалифицированных работников, членов семей.

Важно отметить, что Главным управлением по вопросам миграции МВД России разрабатывается проект федерального закона «О внесении изменений в некоторые законодательные акты Российской Федерации в части предоставления государственных услуг и исполнения функций в сфере миграции», предусматривающий расширение функционала федерального государственного унитарного предприятия «Паспортно-визовый сервис» Министерства внутренних дел Российской Федерации (Предприятия), а также уполномоченных организаций субъектов Российской Федерации. В рамках расширения полномочий Предприятия предполагается привлечение его к участию в осуществлении полномочий и оказанию содействия в предоставлении государственных услуг в сфере миграции в части: 1) оформления и выдачи виз и приглашений на въезд в Российскую Федерацию; 2) осуществления миграционного учета; 3) приема заявлений о продлении срока временного пребывания иностранного гражданина; 4) приема заявлений о выдаче разрешений на временное проживание, видов на жительство; 5) приема разрешительных документов для осуществления иностранными гражданами трудовой деятельности на территории Российской Федерации; 6) приема уведомлений, связанных с пребыванием (проживанием) иностранных граждан и осуществлением ими трудовой деятельности; 7) приема заявлений о приобретении российского гражданства, а также приема уведомлений о наличии у граждан Российской Федерации иного гражданства или о прекращении у них иностранного гражданства; 8) приема заявлений о выдаче паспорта граждани- на Российской Федерации; 9) оказания содействия в проведении обязательной государственной дактилоскопической регистрации иностранных граждан и их фотографирования. Указанные изменения помогут противодействовать коррупционным проявлениям, посредническим и нелегальным коммерческим организациям, часто использующим мошеннические схемы при оказании государственных услуг в сфере миграции; сохранить уровень безопасности и повысить качество оказания государственных услуг; исключить очереди в подразделениях по вопросам миграции территориальных органов МВД России.

Необходимо отметить, что МВД России приступило к разработке концепции нового миграционного закона, который заменит два действующих акта о правовом положении иностранных граждан в РФ и миграционном учете иностранных граждан в РФ.

В документе прописан ряд новых подходов к миграционной политике. Например, планируется убрать трехступенчатость статусов, разрешение на временное проживание (РВП) будет отменено. Планируется введение ID-карт, которые будут содержать все данные об иностранцах, включая номер патента, отпечатки пальцев, а также сведения о месте работы. Такая новация позволит выявлять поддельные документы. Вид на жительство (ВНЖ), согласно наработкам ГУВМ, будет выдаваться либо в общем порядке, либо в упрощенном, но пока критерии не указаны. Также планируется ввести три этапа пребывания иностранцев в РФ краткосрочное (до 90 дней), долгосрочное (для осуществления трудовой деятельности, получения образования, лечения и т. д.) и постоянное.

Таким образом, модернизация государственного управления в сфере миграции затронет все аспекты миграционных правоотношений, включая вопросы пребывания иностранных граждан и лиц без гражданства в Российской Федерации, регулирования трудовой миграции, осуществления контрольно-надзорных полномочий. В рамках плана мероприятий по реализации в 2020-2022 гг. Концепции государственной миграционной политики Российской Федерации на 2019-2025 гг. предусматривается кардинальное изменение мигра- 
ционного законодательства посредством его систематизации.

Подводя итог проведенному исследованию, можно сказать, что пандемия COVID19 оказала существенное влияние на миграционную политику зарубежных государств и Российской Федерации. Страны несмотря на сложное экономическое положение постарались не оставить мигрантов в беде, внедряли новые практики интеграции, продлевали пребывание иностранных граждан в целях недопущения роста неурегулированных мигрантов, оказывали социальную помощь.

\section{СПИСОК ЛИТЕРАТУРЫ}

1. Борьба с коронавирусом (COVID-19). Вклад в глобальные усилия. - Электрон. текстовые дан. Режим доступа: https:/www.oecd.org/coronavirus/en/ (дата обращения: 21.07.2020). - Загл. с экрана.

2. Дмитрий Полетаев «Миграционные последствия “идеального шторма": каким будет влияние пандемии коронавируса на проблемы миграции?». Электрон. текстовые дан. - Режим доступа: https:// russiancouncil.ru/analytics-and-comments/analytics/ migratsionnye-posledstviya-idealnogo-shtorma-kakimbudet-vliyanie-pandemii-koronavirusa-na-problemy/ (дата обращения: 24.07.2020). - Загл. с экрана.

3. Краткий обзор политики МOT - Защита рабочих-мигрантов во время пандемии COVID-19 // Европейский веб-сайт по интеграции. - Электрон. текстовые дан. - Режим доступа: https://ec.europa.eu/ migrant-integration/news/ilo-policy-brief-protectingmigrant-workers-during-the-covid-19-pandemic (дата обращения: 22.07.2020). - Загл. с экрана.

4. Пугин заявил о заинтересованности России в притоке мигрантов. - Электрон. текстовые дан. Режим доступа: https://iz.ru/1031451/2020-07-04/ putin-zaiavil-o-zainteresovannosti-rossii-v-pritokemigrantov?utm_source $=$ yxnews\&utm_medium $=$ desktop\&utm_referrer $=\mathrm{https} \% 3 \mathrm{~A} \% 2 \mathrm{~F} \% 2$ Fyandex. ru\%2Fnews (дата обращения 24.07.2020). - Загл. с экрана.

5. Указ Президента Российской Федерации от 18.04.2020 № 274 «О временных мерах по урегулированию правового положения иностранных граждан и лиц без гражданства в Российской Федерации в связи с угрозой дальнейшего распространения новой коронавирусной инфекции (COVID-19)» // Официальный интернет-портал правовой информации. - Электрон. текстовые дан. - Режим доступа: http://publication.pravo.gov.ru/Document/View/ 0001202004180001 (дата обращения: 21.07.2020). Загл. с экрана.
6. Эксперты ВЭБ оценили влияние вируса на экономику России. - Электрон. текстовые дан. Режим доступа: https://www.rbc.ru/economics/12/04/ 2020/ (дата обращения: 21.07.2020). - Загл. с экрана.

7. Эксперты Moody's предсказали рост миграции внутри России из-за пандемии. Какие регионы рискуют потерять население // РБК. - 20.05.2020. Электрон. текстовые дан. - Режим доступа: https:// www.rbc.ru/economics/20/05/2020/ (дата обращения: 21.07.2020). - Загл. с экрана.

8. COVID-19's impact on migrant communities / / European Web Site On Integration. - 24.06.2020. Electronic text data. - Mode of access: https:// ec.europa.eu/migrant-integration/news/covid-19simpact-on-migrant-communities (date of access: 21.07.2020). - Title from screen.

9. IOM COVID 19 Response - Situation Report 24 (17 July 2020). - Electronic text data. - Mode of access: https://migration.iom.int/reports/iom-covid19-response-situation-report-24-17-july-2020?close= true\&covid-page $=1$ (date of access: 21.07.2020). Title from screen.

10. Migration Data Portal. - Electronic text data. - Mode of access: https://migrationdataportal. org/? $\mathrm{i}=$ stock_abs_\&t $=2019 \& \mathrm{~m}=1$ (date of access: 21.07.2020). - Title from screen.

11. Poland: Solidarity allowance due to COVID-19 for the unemployed applies to foreigners. - Electronic text data. - Mode of access: https://ec.europa.eu/ migrant-integration/news/poland-solidarityallowance-due-to-covid-19-for-the-unemployedapplies-to-foreigners (date of access: 22.07.2020). Title from screen.

12. Return of undocumented afghans. Electronic text data. - Mode of access: https:// afghanistan.iom.int/sites/default/files/Reports/ iom_afghanistan-return_of_undocumented_afghans_situation_report_24-30_may_2020.pdf (date of access: 22.07.2020). - Title from screen.

13. Spain introduces special COVID-19 integration measures. - Electronic text data. - Mode of access: https://ec.europa.eu/migrant-integration/news/spainintroduces-special-covid-19-integration-measures (date of access: 21.07.2020). - Title from screen.

14. Situation at EU external borders in April Detections lowest since 2009. - Electronic text data. Mode of access: https://frontex.europa.eu/mediacentre/news-release/situation-at-eu-external-bordersin-april-detections-lowest-since-2009-mJE5Uv (date of access: 21.07.2020). - Title from screen.

15. Skill measures to mobilise the workforce during the COVID-19 crisis. - Electronic text data. - Mode of access: http://www.oecd.org/coronavirus/policyresponses/skill-measures-to-mobilise-the-workforceduring-the-covid-19-crisis-afd33a65/ (date of access: 22.07.2020). - Title from screen. 


\section{REFERENCES}

1. Borba s koronavirusom (COVID-19). Vkladv globalnye usilija [Tackling Coronavirus (COVID-19). Contributing to a Global Effort]. URL: https://www. oecd.org/coronavirus/en/ (accessed 21 July 2020).

2. Dmitrij Poletaev «Migracionnye posledstvija «idealnogo shtorma»: kakim budet vlijanie pandemii koronavirusa na problemy migracii?» [The Migration Implications of the "Perfect Storm": What Will Be the Impact of the Coronavirus Pandemic on Migration Problems]. URL: https://russiancouncil.ru/analyticsand-comments/analytics/migratsionnye-posledstviyaidealnogo-shtorma-kakim-budet-vliyanie-pandemiikoronavirusa-na-problemy/ (accessed 24 July 2020).

3. Kratkij obzor politiki MOT - Zashhita rabochih-migrantov vo vremja pandemii COVID-19 [ILO Policy Brief-Protecting Migrant Workers During the COVID-19 Pandemic]. European web site on integration. URL: https://ec.europa.eu/migrantintegration/news/ilo-policy-brief-protecting-migrantworkers-during-the-covid-19-pandemic (accessed 22 July 2020).

4. Putin zajavil o zainteresovannosti Rossii v pritoke migrantov [Putin Announced Russias Interest in the Influx of Migrants]. URL: https://iz.ru/1031451/ 2020-07-04/putin-zaiavil-o-zainteresovannosti-rossiiv-pritoke-migrantov?utm_source=yxnews\&utm medium $=$ desktop\&utm_referrer $=$ https $\% 3 \mathrm{~A} \% 2 \mathrm{~F} \%$ 2Fyandex.ru\%2Fnews (accessed 24 July 2020).

5. Ukaz Prezidenta Rossijskoj Federacii ot 18.04.2020 № 274 «O vremennyh merah po uregulirovaniju pravovogo polozhenija inostrannyh grazhdan i lic bez grazhdanstva v Rossijskoj Federacii v svjazi s ugrozoj dalnejshego rasprostranenija novoj koronavirusnoj infekcii (COVID-19)» [Decree of the President of the Russian Federation of 18.04.2020 No. 274 "On Temporary Measures to Settle the Legal Status of Foreign Citizens and Stateless Persons in the Russian Federation because of the Threat of Further Spread of the New Coronavirus Infection (COVID-19)"']. The official internet-portal of legal information. URL: http://publication.pravo.gov.ru/ Document/View/0001202004180001 (accessed 21 July 2020).

6. Jeksperty VJeB ocenili vlijanie virusa na jekonomiku Rossii [VEB Experts Assessed the Impact of the Virus on the Russian Economy]. URL: https:// www.rbc.ru/economics/12/04/2020/5e919e0a9a79473 91241d05b (accessed 21 July 2020).

7. Jeksperty Moody's predskazali rost migracii vnutri Rossii iz-za pandemii. Kakie regiony riskujut poterjat naselenie [Moodys Experts Predicted an Increase in Migration Within Russia Due to the Pandemic. Which Regions Are at Risk of Losing Population]. URL: https://www.rbc.ru/economics/20/ 05/2020/5 ebae4779a7947937ee59d01 (accessed 21 July 2020).

8. COVID-19's Impact on Migrant Communities. URL: https://ec.europa.eu/migrant-integration/news/ covid-19s-impact-on-migrant-communities (accessed 21 July 2020).

9. IOM COVID 19 Response-Situation Report 24 (17 July 2020). URL: https://migration.iom.int/ reports/iom-covid-19-response-situation-report-24-17july-2020? close $=$ true \& covid - page $=1)($ accessed 21 July 2020).

10. Migration Data Portal. URL: https:// migrationdataportal.org/?i=stock_abs_\&t=2019\&m=1 (accessed 21 July 2020).

11. Poland: Solidarity Allowance Due to COVID-19 for the Unemployed Applies to Foreigners. URL: https://ec.europa.eu/migrantintegration/news/poland-solidarity-allowance-dueto-covid-19-for-the-unemployed-applies-toforeigners (accessed 22 July 2020).

12. Return of Undocumented Afghans. URL: https://afghanistan.iom.int/sites/default/files/Reports/ iom_afghanistan-return_of_undocumented_afghanssituation_report_24-30_may_2020.pdf(accessed 22 July 2020).

13. Spain Introduces Special COVID-19 Integration Measures. URL: https://ec.europa.eu/ migrant-integration/news/spain-introduces-specialcovid-19-integration-measures (accessed 21 July 2020).

14. Situation at EU External Borders in AprilDetections Lowest Since 2009. URL: https:// frontex.europa.eu/media-centre/news-release/ situation-at-eu-external-borders-in-april-detectionslowest-since-2009-mJE5Uv) (accessed 21 July 2020).

15. Skill Measures to Mobilise the Workforce During the COVID-19 Crisis. URL: http://www.oecd. org/coronavirus/policy-responses/skill-measures-tomobilise-the-workforce-during-the-covid-19-crisisafd33a65/ (accessed 22 July 2020). 


\section{ПРОГНОЗНЫЕ СЦЕНАРИИ ПОЛИТИЧЕСКИХ ТРАНСФОРМАЦИЙ}

\section{Information About the Authors}

Vladimir J. Zorin, Doctor of Sciences (Politics), Professor, Chief Researcher, Institute of Ethnology and Anthropology named after N.I. Miklouho-Maclay of the Russian Academy of Sciences, Prosp. Leningradsky, 49, 125993 (GSP-3) Moscow, Russian Federation; Professor, Department of Political Science, Financial University Under the Government of the Russian Federation, Prosp. Leninsky, 32a, 119334 Moscow, Russian Federation, v.y.zorin@mail.ru, https://orcid.org/0000-0003-1344-5765

Vladimir A. Voloh, Doctor of Sciences (Politics), Associate Professor, Professor, Department of Public Administration and Political Technologies, State University of Management, Prosp. Ryazansky, 99, 109542 Moscow, Russian Federation, v.volokh@yandex.ru, https://orcid.org/0000-0003-1292-7631

Vera A. Suvorova, Candidate of Sciences (Politics), Associate Professor, Department of Public Administration and Political Technologies, State University of Management, Prosp. Ryazansky, 99, 109542 Moscow, Russian Federation, sailor_mun@mail.ru, https://orcid.org/0000-0002-9072-3039

\section{Информация об авторах}

Владимир Юрьевич Зорин, доктор политических наук, профессор, главный научный сотрудник, Институт этнологии и антропологии им. Н.И. Миклухо-Маклая РАН, просп. Ленинградский, 49, 125993 (ГСП-3) г. Москва, Российская Федерация; профессор департамента политологии, Финансовый университет при Правительстве РФ, просп. Ленинский, 32а, 119334 г. Москва, Российская Федерация, v.y.zorin@mail.ru, https://orcid.org/0000-0003-1344-5765

Владимир Александрович Волох, доктор политических наук, доцент, профессор кафедры государственного управления и политических технологий, Государственный университет управления, просп. Рязанский, 99, 109542 г. Москва, Российская Федерация, v.volokh@yandex.ru, https://orcid.org/0000-0003-1292-7631

Вера Александровна Суворова, кандидат политических наук, доцент кафедры государственного управления и политических технологий, Государственный университет управления, просп. Рязанский, 99, 109542 г. Москва, Российская Федерация, sailor_mun@mail.ru, https://orcid.org/0000-0002-9072-3039 